\title{
Freud: gobiernos terminables e interminables
}

\author{
JUAN DORADo ROMERo*
}

Artículo recibido: 30 de septiembre de 2014

Artículo aprobado: 20 de febrero de 2015

Doi: dx.doi.org/10.12804/desafios27.2.2015.02

Para citar este artículo: Dorado, J. (2015). Freud: gobiernos terminables e interminables. Desafíos, 27(II), 53-97. Doi: dx.doi.org/10.12804/desafios27.2.2015.02

\section{Resumen}

En este artículo, estudiamos algunas de las contribuciones para la teoría politica del trabajo de Sigmund Freud. A raíz de los resultados de sus investigaciones sobre el funcionamiento del psiquismo bumano, el pensamiento de Freud evolucionará desde una perspectiva elitista y autoritaria hacia un pensamiento democrático del mundo interno, basado en la necesidad de establecer limites benignos a las fantasías de omnipotencia que marcan la ciencia y la politica modernas.

Palabras clave: Freud, omnipotencia, dictadura de la razón, democratización del self.

\footnotetext{
* Investigador predoctoral en el Departamento de Ciencia Política y de la Administración II de la Universidad Complutense de Madrid; miembro del proyecto de investigación "La trascendencia de la retórica en la genealogía del Estado: la democratización del self" (CSO2010-18547).Correo electrónico: jdoradoromero@gmail.com
} 


\title{
Freud: Terminable and Interminable Governments
}

\begin{abstract}
This article examines some of the contributions to political theory offered by the work of Sigmund Freud. Based on the results of his research on the human psyche, Freud's thinking evolved from an authoritarian elitist perspective towards a more democratic understanding of the internal world. He sought to establish benign limits to the fantasies of omnipotence that frame modern science and politics.
\end{abstract}

Keywords: Freud, omnipotence, the dictatorship of reason, democratization of the self.

\section{Freud: governos termináveis e intermináveis}

\begin{abstract}
Resumo
Neste artigo, estudamos algumas das contribuições para a teoria politica do trabalho de Sigmund Freud. A causa dos resultados de suas pesquisas sobre o funcionamento do psiquismo humano, o pensamento de Freud evolucionará desde uma perspectiva elitista e autoritária para um pensamento democrático do mundo interno, baseado na necessidade de estabelecer limites benignos às fantasias de omnipotências que marcam a ciência e a politica moderna.
\end{abstract}

Palavras-chave: Freud, omnipotência, ditadura da raz̃ão, democratização do self.

"El conocimiento verdadero del bien y del mal, en cuanto verdadero, no puede reprimir ningún afecto". Spinoza (2013, p. 327)

\section{Introducción}

Quizás el lector de este trabajo considere arriesgado o gratuito considerar a Sigmund Freud (1856-1939) como un pensador político. Sin embargo, en realidad, con esto no hacemos más que escucharle directamente e interpretar lo que él mismo nos sugiere. 
Cuando se atrevió con el relato de su vida en su Autobiografía de 1925, el mismo Freud apunta que su elección profesional de la carrera médica no se debía a ninguna vocación irrenunciable. Antes, al contrario, Freud dice: "[E]n aquellos años juveniles no sentía predilección especial ninguna por la actividad médica, ni tampoco la he sentido después" (Freud, 1925, p. 2762). Confiesa que lo que lo 'dominaba' era "una especie de curiosidad relativa más bien a las circunstancias humanas que a los objetos naturales" (p. 2762). Acto seguido, añade que, desde muy joven, estuvo genuinamente interesado por los temas políticos: "[B]ajo la poderosa influencia de una amistad escolar con un niño mayor que yo, que llegó a ser un destacado político, se me formó el deseo de estudiar leyes como él y de obligarme a actividades sociales" (p. 2762).

Al final de este ensayo autobiográfico, ampliado en 1935, Freud vuelve sobre el mismo tema, declarando que en los últimos años su vida ha sufrido 'un cambio significativo', de este modo: "[Los] intereses adquiridos en la última parte de mi vida han retrocedido, en tanto que los más originales y antiguos se han vuelto prominentes una vez más" (p. 2798). Tras lamentar que en los últimos años apenas ha realizado alguna contribución importante a la teoría psicoanalítica, asocia esta circunstancia a una alteración en su propia persona, "lo que pudiera ser descrito como una fase de desarrollo regresivo" (pp. 2798-2799). Freud siente que, después de tantos años de paciente labor de investigador del psiquismo humano, sus aspiraciones vuelven a ser las de su infancia y juventud. Resulta admirable que, desde el 'cenit' de su vida, este pensador reconozca ante sus lectores que todo su recorrido vital ha sido un largo rodeo para retornar al origen: "Mi interés luego de un largo détour en las ciencias naturales, la medicina y la psicoterapia, volvió a los problemas culturales que tanto me habían fascinado largo tiempo atrás, cuando era un joven apenas con la edad necesaria para pensar" (p. 2799).

En el mundo interno, ese tipo especial de inteligencia silenciosa que él tanto se había empeñado en estudiar, su presente, por fin, se había convertido en su pasado. Se había dado cuenta de que el progreso lineal hacia adelante no tenía sentido en los vastos paisajes de su 
alma, donde, en cualquier momento, Sigmund, el grandioso intelectual, pasaba a ser Schlomo, su segundo nombre, aquel que, al nacer, su padre, Jacob Freud (1815-1896), había anotado en la Biblia familiar y que no había sobrevivido a su adolescencia (Gay, 2010, p. 27). El niño judío que anhelaba dedicarse a los asuntos de la política se hace fuerte y consciente en los últimos años de su vida, y ya no tiene miedo a reivindicar sus motivaciones más hondas y expresar sus opiniones al respecto. Sin embargo, de lo que quizá Freud no pudo o no quiso darse cuenta es que Schlomo nunca se había ido, que siempre estuvo acompañando a Sigmund. Es cierto que durante muchos años estuvo relegado a un segundo o tercer plano ante el empuje del indomable Freud del mundo externo, pero pacientemente, en su mundo interno, Schlomo estuvo jugando y trabajando para que en sus escritos apareciesen una y otra vez los acordes de una música con un sonido genuinamente político.

\section{El peligro interior}

En su consulta, Freud observó cómo en los relatos letárgicos de sus pacientes de ambos sexos aparecían deseos destructivos o relativos al goce sexual que atentaban no solo contra las convenciones morales de la sociedad de su tiempo, sino también contra las leyes vigentes que formalizaban esas convenciones. El paso del deseo a la realidad de esas pulsiones acarrearían sin duda un daño para la convivencia, al estar marcadas por un egoísmo extremo, por un retorno a un "primitivo infantilismo" (Freud, 1916, p. 2253) de carácter salvaje y reacio a aceptar la imposición de límites externos. Los sueños representan el reinado inmortal de la infancia del ciudadano.

No solamente hemos hallado que los materiales de que se componen los sucesos olvidados de la vida infantil son accesibles al sueño, sino que hemos visto, además, que la vida psíquica de los niños, con todas sus particularidades, su egoísmo, sus tendencias incestuosas, etc., sobrevive en lo inconsciente y emerge en los sueños, los cuales nos hacen retornar cada noche a la vida infantil. Constituye esto una confirmación de que lo inconsciente de la vida psíquica no es otra cosa que lo infantil (p. 2252). 
Estas ideas oníricas suponían la herencia arcaica en contra de la que se habían edificado la civilización y la conciencia moral. De hecho, toda cultura, sostiene Freud, se basa en sacrificar esos instintos primitivos para lograr la convivencia de individuos con impulsos infantiles y narcisistas en una comunidad que prevenga el daño recíproco: "Es forzoso reconocer la medida en que la cultura reposa sobre la renuncia de las satisfacciones instintuales... Esta frustración cultural rige el vasto dominio de la relaciones sociales entre los seres humanos, y ya sabemos que en ella reside la causa de la hostilidad opuesta a toda cultura" (Freud, 1930, p. 3038).

A medida que el lector avanza en las páginas de El malestar en la cultura (1930), se irá dando cuenta de que a Freud le preocupaba la honda insatisfacción, infelicidad podríamos decir, que los ciudadanos sentían ante una cultura hipócrita, basada en la vigilancia de las apariencias, especialmente en el terreno sexual. Uno de los cimientos de la cultura, quizás el más original y de consecuencias más profundas, sería la prohibición del incesto. La estela de esta prohibición aún se deja sentir con fuerza en nuestra identidad no consciente, de ahí que Freud la considere "la más cruenta mutilación que haya sufrido la vida amorosa del hombre en el curso de los tiempos" (p. 3041).

La cultura, para avanzar y prosperar, necesitaría, según el planteamiento freudiano, de un orden impuesto a la fuerza contra los desobedientes, y el sexo ha sido considerado durante siglos un factor con un potencial desordenante, porque nos fija en lo corporal y lo terreno, en la dependencia de la persona amada o deseada, contra los altos vuelos de la religión y la filosofía. "He aquí por qué los sabios de todos los tiempos trataron de disuadir tan insistentemente a los hombres de la elección de este camino [del amor sexual], que, sin embargo, conservó todo su atractivo para gran número de seres" (p. 3040). Puesto que el argumento de autoridad no ha logrado nunca los efectos esperados para domeñar los instintos sexuales de hombres y mujeres, la opción más eficaz, al tiempo que dolorosa, ha sido la de imponer por la fuerza unas prácticas y reprimir duramente el resto de alternativas. 
Al hacerlo [la cultura] adopta frente a la sexualidad una conducta idéntica a la de un pueblo o una clase social que haya logrado someter a otra a su explotación. El temor a la rebelión de los oprimidos induce a adoptar medidas de precaución más rigurosas. Nuestra cultura europea occidental corresponde a un punto culminante de este desarrollo (p. 3042).

Estas opiniones reflejan el talante reformador de un pensador que defendía liberar a la sexualidad humana de unas cadenas demasiado rígidas. Sin embargo, la cultura, pensaba Freud, no solo ha necesitado domesticar los instintos eróticos de los ciudadanos. Existían otras tendencias innatas, que aparecen mezcladas frecuentemente con las anteriores, cuya represión se ha convertido en el distintivo de toda formación cultural y en la condición esencial de las comunidades políticas. Hablamos de los instintos hostiles y agresivos que también forman una parte irreductible de la identidad del ciudadano. Los preceptos éticos nacen, en opinión de Freud, de un idealismo de la naturaleza humana que no encuentra correspondencia con la experiencia cotidiana. La religión y la moral se habrían dedicado a la negación omnipotente de una realidad demasiado tenebrosa. Freud ataca en particular al mandamiento ético de amarás al prójimo como a ti mismo, que ha acabado convertido en el frontispicio del cristianismo.

Además de 'irrealizable', este precepto, que constituye "el rechazo más intenso de la agresividad humana", supone un peligro para la felicidad individual, ya que "tamaña inflación del amor no puede menos que menoscabar su valor, pero de ningún modo conseguirá remediar el mal" (p. 3066). Es insensato, arguye nuestro autor, pedir que mostremos amor por nuestros enemigos, es decir, amar a quienes no nos aman. Supone un desconocimiento de lo que significa el amor, porque este "me impone obligaciones que debo estar dispuesto a cumplir con sacrificios" (p. 3044), de forma que solo podemos amar verdaderamente a quien lo merezca por alguna razón. El hecho de exigir que amemos a un extraño cualquiera es, además, injusto para aquellos que sí nos aman, que aprecian nuestro amor "como una demostración de preferencia, y les haría injusticia si los equiparase con un extraño" (p. 3044). Si a esto sumamos que este solemne 
mandamiento nos obligaría a amar a quienes realizan acciones malvadas, el resultado sería catastrófico: "El cumplimiento de los supremos preceptos éticos significaría un perjuicio para los fines de la cultura al establecer un premio directo a la maldad" (p. 3045).

La verdad oculta tras de todo esto, que negaríamos de buen grado, es la de que el hombre no es una criatura tierna y necesitada de amor, que sólo osaría defenderse si se le atacara, sino, por el contrario, un ser entre cuyas disposiciones instintivas también debe incluirse una buena porción de agresividad. Por consiguiente, el prójimo no le representa únicamente un posible colaborador y objeto sexual, sino también un motivo de tentación para satisfacer en él su agresividad, para explotar su capacidad de trabajo sin retribuirla, para aprovecharlo sexualmente sin su consentimiento, para apoderarse de sus bienes, para humillarlo, para ocasionarle sufrimientos, martirizarlo y matarlo. Homo homini lupus: ¿quién se atrevería a refutar este refrán, después de todas las experiencias de la vida y de la Historia? (p. 3046).

En este extracto, podemos presenciar a un Freud desafiante, dispuesto a confrontar con sus potenciales lectores sus terribles descubrimientos acerca de los instintos agresivos que empujan a la psique humana a destruir los logros civilizatorios que también ella misma ha llevado a cabo. ${ }^{1}$ El carácter violento o agresivo de los seres humanos es de naturaleza 'primordial', lo que hace que 'la hostilidad' entre ellos sea inextirpable, un hecho con el que debemos contar si no queremos caer en un ilusiones o promesas imposibles de realizar. Esto provoca

\footnotetext{
1 Ante una de las críticas negativas que las tesis expresadas en El malestar en la cultura recibieron en los Estados Unidos, un país que Freud consideraba poblado por gente mojigata e ingenua, el psiquiatra expresó que esa crítica "es exactamente tan estúpida e ignorante como cabe esperar de un periodista norteamericano" (citado en Gay, 2010, p. 628). El biógrafo también cita una respuesta a Ernest Jones en la que Freud le confía que "América es gigantesca, pero un error gigantesco" (p. 626). Para un repaso de las actitudes antinorteamericanas de Freud, ver Gay (2010, pp. 616-634). Por otra parte, consideramos sintomática de la actitud estadounidense hacia los aspectos más perturbadores de los descubrimientos de Freud que un teórico político como Sheldon S. Wolin -cuyas opiniones son muy críticas con las insuficiencias del sistema político de su país- desconfíe de "that rancorous and divisive discourse that goes by the deceptively unified name of psychoanalysis" (Wolin, 1991, p. 192).
} 
que, desgraciadamente, "la sociedad civilizada se vea constantemente al borde de la desintegración” (Freud, 1930, p. 3046). Su pesimismo acerca de una reforma o evolución de esta constitución humana es rotundo. Ninguna comunidad de intereses o de trabajo puede mantener indefinidamente la 'cohesión' de un grupo humano, "pues las pasiones instintivas son más poderosas que los intereses racionales" (p. 3046). A nuestras organizaciones sociales no les quedaría más remedio que una y otra vez intentar levantar muros que detengan la inagotable agresividad humana.

De ahí, pues, ese despliegue de métodos destinados a que los hombres se identifiquen y entablen vínculos amorosos coartados en su fin; de ahí las restricciones de la vida sexual, y de ahí también el precepto ideal de amar al prójimo como a sí mismo, precepto que efectivamente se justifica, porque ningún otro es, como él, tan contrario y antagónico a la primitiva naturaleza humana. Sin embargo, todos los esfuerzos de la cultura destinados a imponerlo aún no han logrado gran cosa... En un momento determinado, todos llegamos a abandonar, como ilusiones, cuantas esperanzas juveniles habíamos puesto en el prójimo; todos sufrimos la experiencia de comprobar cómo la maldad de éste nos amarga y dificulta la vida (p. 3046).

La abolición de la propiedad privada, como pretendían los comunistas, tampoco sería la panacea contra las fuertes tendencias antisociales, contra esa grieta incapaz de ser cerrada. Al fin y al cabo, "el instinto agresivo no es una consecuencia de la propiedad, sino que regía casi sin restricciones en épocas primitivas, cuando la propiedad aún era bien poca cosa" (p. 3047). Más aún, esa hostilidad también "constituye el sedimento de todos los vínculos cariñosos y amorosos entre los hombres, quizá con la única excepción del amor que la madre siente por su hijo varón” (p. 3047). Esta excepción a su tesis de la omnipresencia de la agresividad en las relaciones humanas, la del amor de madre a su niño, es una idea defendida por Freud desde los inicios de su producción teórica (Freud, 1900, p. 589). Este amor sin condiciones, propio de un tipo específico de maternidad-obsérvese que Freud no reconoce ningún carácter excepcional a las relaciones 
entre padres e hijos, tampoco a las que se establecen entre una madre y su hija-, aparecería como el salvavidas, de hecho el único objeto bueno y protector al que agarrarse ante el siempre posible naufragio de nuestras vidas (masculinas).

Otro fenómeno que se reproduce en las más diversas culturas es $\mathrm{el}$ narcisismo de las pequeñas diferencias (Freud, 1930, p. 3048), tan profusamente extendido en los ambientes de los partidos políticos y en el entorno académico, pero que se da con especial virulencia entre países o comunidades vecinas. Freud asegura que el hombre "no se siente nada a gusto" si no puede dar satisfacción a sus impulsos agresivos (p. 3047). Así, aun cuando pueda unirse amorosamente en comunidades cada vez más grandes, el ciudadano exigirá, de forma no consciente, que siempre quede un resto excluido formado por esos otros "en quienes descargar los golpes" (p. 3048). Esta actitud serviría como refuerzo de la cohesión comunitaria. Un mecanismo que, destaca Freud, ha contado con el pueblo judío como la víctima propiciatoria de las naciones europeas desde la Edad Media (p. 3048).

Freud reconoce que incluso él mismo se resistió durante mucho tiempo a aceptar la profunda carga de destructividad que alberga el alma humana. Por eso mismo tampoco le sorprendía la 'aversión' que despertaban estas ideas suyas. En todo caso, es comprensible que ante la angustia nos refugiemos en ilusiones. Sarcásticamente, Freud añade que "a quienes creen en los cuentos de hadas no les agrada oír mentar la innata inclinación del hombre hacia 'lo malo', a la agresión, a la destrucción y con ello también a la crueldad" (pp. 3051-3052). Con fina ironía, acabará aconsejando a sus lectores que, si quieren evitarse problemas, no sigan sus pasos. El impío científico atribuye a la piedad religiosa que impregna la cultura europea la responsabilidad principal de esta actitud negadora de nuestra agresividad instintiva.

¿Acaso Dios no nos creó a imagen de su propia perfección? Pues por eso nadie quiere que se le recuerde cuán difícil resulta conciliar la existencia del mal... con la omnipotencia y la soberana bondad de Dios. El Diablo aun sería el mejor subterfugio para disculpar a Dios, pues desempeñaría la misma función económica 
de descarga que el judío cumple en el mundo de los ideales arios. Pero aun así se podría pedir cuentas a Dios tanto de la existencia del Diablo como del mal que encarna. Frente a tales dificultades conviene aconsejar a todos que rindan profunda reverencia, en cuantas ocasiones se presenten, a la naturaleza esencialmente moral del hombre; de esta manera se gana el favor general y se le perdonan a uno muchas cosas (p. 3052).

Sin embargo, tras esta ardorosa defensa de sus ideas sobre la disposición innata de la maldad y la crueldad humanas, Freud tenía que hacer frente a las inquietantes consecuencias que estas acarreaban. Un científico no debe hacerse ilusiones, sobre todo si sus hallazgos contradicen sus primeras hipótesis. Como mantenía en Elporvenir de una ilusión (1927), defendiendo la actitud científica contra la religiosa: "Mis ilusiones —aparte de no existir castigo alguno para quien no las comparte- no son irrectificables, como las religiosas, ni integran su carácter obsesivo. Si la experiencia demostrase... que nos habíamos equivocado, renunciaremos a nuestras esperanzas" (Freud, 1927, p. 2990). ${ }^{2}$ Y Freud había estado equivocado respecto a la importancia determinante de los instintos agresivos, puesto que, de hecho, eran tan fundamentales como los instintos sexuales a los que había prestado atención desde el principio de su labor investigadora. Así lo reconoce en su vejez: "Ya no logro comprender cómo fue posible que pasáramos por alto la ubicuidad de las tendencias agresivas y destructivas no eróticas, dejando de concederles la importancia que merecen en la interpretación de la vida" (Freud, 1930, p. 3051).

Dispuesto a reconocer esa importancia del instinto de destrucción, también consideró así mismo necesario extraer dos consecuencias. En primer lugar, que esa tendencia a la agresividad "constituye el mayor obstáculo con que tropieza la cultura” (p. 3052). Un obstáculo que es tan irreductible como peligroso, pues suponía el instrumento

\footnotetext{
2 En el mismo trabajo, un poco más adelante, volverá a incidir en la misma idea: "Nosotros estamos libres de semejantes servidumbres [religiosas]. Hallándonos dispuestos a renunciar a buena parte de nuestros deseos infantiles, podemos soportar muy bien que algunas de nuestras esperanzas demuestren no ser sino ilusiones" (Freud, 1927, p. 2991).
} 
siempre disponible con el que el ciudadano podía dar rienda suelta a sus fantasías omnipotentes que, a su vez, son incompatibles con el funcionamiento pacífico y democrático de la polis.

\begin{abstract}
Aun donde [la tendencia agresiva] aparece sin propósito sexual, aun en la más ciega furia destructiva, no se puede dejar de reconocer que su satisfacción se acompaña de extraordinario placer narcisista, pues ofrece al yo la realización de sus más arcaicos deseos de omnipotencia (p. 3052).
\end{abstract}

La otra consecuencia sería una derivación de la frustración que la cultura ejerce sobre los instintos más primarios, los sexuales y los destructivos, a la que ya hemos hecho referencia. Y que genera en el ciudadano un difuso malestar, una "miseria psicológica de las masas" (p. 3049), una infelicidad recurrente que estimula la búsqueda de soluciones finales que acaben de una vez por todas con esa insatisfacción de cuyo origen el ciudadano no tendría consciencia. "Si la cultura impone tan pesados sacrificios, no sólo a la sexualidad, sino también a las tendencias agresivas, comprenderemos mejor por qué al hombre le resulta tan difícil alcanzar en ella la felicidad" (p. 3048).

\title{
2. ¿Dictadura de la razón?
}

Esa miseria psicológica, ese malestar de la cultura, esa insatisfacción podría provocar grandes males en la civilización europea. Los acontecimientos políticos en Alemania y Austria que se precipitaron en los años treinta — recordemos que El malestar de la cultura se publicó en 1930 - terminarían por dar la razón a Freud sobre el alcance que ese instinto de destrucción tenía en el mundo interno de los ciudadanos. Ahora, no obstante, nos interesa mostrar cuál fue la primera propuesta freudiana a ese malestar. Ante la rebelión de los instintos eróticos y destructivos, ante el poderío del ello —entendido como el espacio mental donde esos impulsos refractarios a la racionalidad y a los logros intelectuales tienen su metafórica morada-, Freud optará por un reforzamiento del ejecutivo en el foro interno del ciudadano. Se convertirá en un valedor teórico de la solución autoritaria, de una dictadura del yo racional, a expensas de despreciar la descripción 
sobre la peculiar correlación de fuerzas en el aparato anímico que el mismo Freud había expuesto anteriormente en su trabajo. ¿Era esa una respuesta angustiada a sus descubrimientos? ¿Se dejaba llevar por el pensamiento mágico que él ya veía superado en la concepción científica del mundo? Parece que el teórico riguroso de la mente podía, en ocasiones, actuar como un hechicero capaz de exorcizar con palabras mágicas los demonios de la sociedad. ${ }^{3}$ Consideremos esta cuestión más detenidamente.

En una respuesta a una carta del físico Albert Einstein (1879-1955), en donde este le preguntaba a Freud sobre las posibilidades psicológicas de prevenir futuras guerras, el psiquiatra vuelve a repetir en esta misiva, fechada en 1932 — aunque publicada un año después-, similares argumentos a los que hemos apenas expuesto, incidiendo en que debe concluirse que "serán inútiles los propósitos para eliminar las tendencias agresivas del hombre" (Freud, 1933, p. 3213). Por el contrario, lo máximo a lo que podríamos aspirar es a "intentar desviarlas, al punto que no necesiten buscar su expresión en la guerra" (p. 3213).

A continuación, Freud añade que hay que tener en cuenta que "el hecho de que [los seres humanos] se dividan en dirigentes y dirigidos es una expresión de su desigualdad innata e irremediable". Además, estos "subordinados forman la inmensa mayoría, necesitan una autoridad que adopte para ellos las decisiones" (pp. 3213-3214). Ahora bien, ¿qué quiere decir Freud con que la desigualdad entre los seres humanos es "innata e irremediable"? ¿Supone esta afirmación la imposibilidad práctica de la democracia como régimen político basado en el principio de igualdad? Esta sería, en nuestra opinión, una interpretación simplista y, por lo tanto, errada. Por el contrario, Freud está haciendo referencia a una verdad incómoda, pero que, no obstante, expresa así mismo la raíz de la política. Como señala Javier Roiz, glosando a su vez las ideas de Maimónides (1135-1204), “[e]1 hombre nace impotente, en una posición de poder cero, y depende

\footnotetext{
Sobre este uso prolífico de los gestos mágicos en la filosofía moderna, aunque centrado en el caso de Hegel, ver el excelente trabajo de Voegelin (1990, pp. 213-255).
} 
de su familia o de quienes les sustituyan para sobrevivir. Depende de su ciudad también" (Roiz, 2008, p. 88).

Por lo tanto, la vida del ciudadano es un aprendizaje político para elaborar su capacidad, así como su necesidad natural, de gobierno, es decir, de solucionar su desvalimiento original. "Todos nacemos en una situación de impotencia y jamás perderemos esa necesidad de ser gobernados y gobernar. Mandar y obedecer es una capacidad nuestra que más bien puede llamarse necesidad de vida" (p. 89). En esa situación de dependencia en la que todos los futuros ciudadanos se han encontrado durante su infancia - y cuya amenaza se dejará sentir para siempre en un mundo interno sin sentido del tiempo ni del espacio-, es cierto que está en juego la vida o la muerte del infante, así como también es constante el riesgo de que sea abandonado a la intemperie, con la consiguiente posibilidad de caer en la locura, la muerte psíquica. No se deben minusvalorar los peligros asociados a esta desigualdad radical. Pero también es cierta la otra cara del asunto. Las primeras autoridades también han dejado 'buenos recuerdos' al ciudadano, en forma de "placeres, satisfacciones, protección y seguridad" (p. 91). Esa "dominación de una persona sobre otra es una necesidad natural" (p. 92), por el simple hecho de que sin ella, sin unas autoridades que nos alimenten, que nos acompañen y que nos limiten no podríamos, sencillamente, sobrevivir. Es en este sentido como, pensamos, debería ser interpretada la aseveración de Freud sobre el hecho innato e irremediable de estar gobernados por otros.

Lo que ya no entra en el ámbito de los hechos incontrovertibles, ni de las certezas empíricas, es la forma concreta que debería adquirir ese gobierno. Freud reconoce a Einstein que "con toda probabilidad" su opción de gobierno del mundo externo e interno, que evitaría las guerras futuras, así como los conflictos dentro de una misma comunidad, es "una esperanza utópica" (Freud, 1933, p. 3214). Pero no por ello deja de expresarla en términos claros y rotundos:

$[\ldots]$ es preciso poner mayor empeño en educar una capa superior de hombres dotados de pensamiento independiente, inaccesibles a la intimidación, que breguen por la verdad y a los cuales corres- 
ponda la dirección de las masas dependientes... La situación ideal sería, naturalmente, la de una comunidad de hombres que hubieran sometido su vida instintiva a la dictadura de la razón. Ninguna otra cosa podría llevar a una unidad tan completa y resistente de los hombres, aunque se renunciara a los lazos afectivos entre ellos... Los restantes caminos para evitar indirectamente la guerra son por cierto más accesibles, pero en cambio no prometen un resultado inmediato (p. 3214). ${ }^{4}$

En esta 'situación ideal' comprobamos cómo aparece la analogía entre 'masas' e instintos, siendo las primeras una especie de proyección a gran escala de los segundos. Las 'masas dependientes', por su propia seguridad, parece sugerir Freud, deberían ser dirigidas por una 'capa superior de hombres' que, además, son descritos con tonos heroicos, ya que, para llevar a cabo su importante función de guía de las masas, deben ser 'inaccesibles a la intimidación' con el objetivo declarado de que la 'verdad' reluzca siempre. Su función, además de las propias de dirigir una comunidad diversa y potencialmente conflictiva, será, por lo tanto, la de disipar las ilusiones de los ciudadanos, las mismas ideas erróneas que conducen a las guerras y amenazan el orden instituido. Esa élite racional, tan afín a los reyes filósofos del platonismo, ${ }^{5}$ deberá velar porque cada uno de los miembros de la 'comunidad de hombres' haya "sometido su vida instintiva a la dictadura de la razón". ${ }^{6}$ La meta de tal organización política, que, como observamos, busca sincronizar una dictadura externa con otra interna, es la de conseguir la 'unidad' social y anímica, aun a costa de los 'lazos afectivos', cuya ambivalencia podría resultar un peligro para la cohesión que se persigue. El carácter eminentemente ejecutivo y voluntarioso de toda esta propuesta

\footnotetext{
4 Énfasis añadido.

5 En la República, Platón hace decir a su maestro Sócrates: "A menos... que los filósofos reinen en las ciudades o cuantos ahora se llaman reyes y dinastas practiquen noble y adecuadamente la filosofía, vengan a coincidir una cosa y otra, la filosofía y el poder político, y sean detenidos por la fuerza los muchos caracteres que se encaminan separadamente a una de las dos, no hay, amigo Glaucón, tregua para los males de las ciudades, ni tampoco, según creo, para los del género humano" (2002, 473d-e, p. 334).

6 Sobre la presencia de veleidades platónicas y elitistas en las teorías freudianas, ver Rieff (1966, p. 243) y Boesche (1996, pp. 303-306).
} 
'ideal' queda patente con el argumento de que esta solución política sería la más satisfactoria porque 'promete un resultado inmediato'. Se trataría, por lo tanto, de una utopía de la inmediatez.

Ese mismo año de 1932, ya en la última década de su vida, y en el último capítulo de las Nuevas lecciones introductorias al psicoanálisis, que trataba sobre una posible Weltanschaunng (concepción del mundo) del psicoanálisis - Freud considera que su concepción del mundo no es de ningún modo particular, sino coincidente con la de la ciencia en general-, el investigador austríaco también insiste en ese autoritarismo intelectual. El capítulo parte de la consideración de que la religión es el "único enemigo serio" (Freud, 1932, p. 3192) que se opone a la ciencia, puesto que es "un magno poder que dispone de las más intensas emociones humanas" (p. 3193); Freud la entiende como un conjunto de ideas y prácticas que expresan la confianza neurótica en la omnipotencia del pensamiento, instrumento fantástico con el que combatiríamos nuestros miedos ancestrales al dolor y al abandono. De ahí que, mediante la relación piadosa entre el creyente y su dios, "el individuo se ha asegurado, con la oración, una influencia directa sobre la voluntad divina y, con ella, una participación en la omnipotencia divina" (p. 3194).

En cualquier caso, Freud pensaba que "sus doctrinas llevan impreso el sello de los tiempos en que surgieron, el sello de la infancia ignorante de la humanidad" (p. 3197). Deberíamos, por esa misma razón, desconfiar de sus consuelos falaces. Desde la atalaya del científico adulto y descreído que otea la "marcha evolutiva de la Humanidad", la religión no es sino "una contrapartida de la neurosis que el individuo civilizado atraviesa en su camino desde la infancia a la madurez" (p. 3197). ${ }^{7}$

\footnotetext{
7 Un Freud muy seguro de sus tesis sobre la génesis del sentimiento religioso afirma que "[e]l psicoanálisis ha aportado la última contribución a la crítica de la concepción religiosa del universo, atribuyendo el origen de la religión a la necesidad de protección del niño inerme y débil y derivando sus contenidos de los deseos y necesidades de la época infantil, continuados en la vida adulta" (1932, p. 3197). En Elporvenir de una ilusión, Freud ya había sentenciado a muerte el fenómeno religioso: "La religión sería la neurosis obsesiva de la colectividad humana, y lo mismo que la del niño, provendría del complejo de Edipo en la
} 
En el contexto de esta 'pugna' contra la religión, es donde Freud plantea su 'mejor esperanza' de que "el intelecto —el espíritu científico, la razón- logre algún día la dictadura sobre la vida psíquica del hombre" (p. 3199). Una dictadura que, por supuesto, sería benigna, como dice el discurso habitual entre quienes defienden este tipo de regímenes políticos. ${ }^{8} \mathrm{El}$ intelecto, sostiene Freud, o como más comúnmente se le conoce, "la razón... pertenece a aquellos poderes de los que más justificadamente podemos esperar una influencia aglutinante sobre los hombres, a los que tan difícil se hace mantener unidos y, por tanto, gobernar" (p. 3199). Este interés genuino por encontrar la mejor forma de gobierno a las comunidades humanas vuelve a mostrar el marcado carácter político del proyecto freudiano. La bondad de esta dictadura intelectual se debería a 'la esencia misma de la razón'. Pero si en la carta a Einstein el poder de la razón era tan sólido que era posible prescindir de los afectos que ligan a los ciudadanos entre sí, en este trabajo Freud no deja de lado este elemento y los incluye en el cuadro. Así, la dictadura de la razón "garantiza que nunca dejará de otorgar su debido puesto a los impulsos afectivos del hombre y a lo que por ellos es determinado" (p. 3199). Aunque no deberíamos ilusionarnos con este reconocimiento de los afectos, que solo podrían hacernos bien si se encuentran sometidos a un intelecto que tiene mucho de director de orquesta. Bajo su batuta se conseguiría nada menos que la unión y la armonía cívicas: "La coerción común de tal reinado de la razón resultará el más fuerte lazo de unión entre los hombres y procurará otras armonías" (p. 3199).

relación con el padre. Conforme a esta teoría hemos de suponer que el abandono de la religión se cumplirá con toda la inexorable fatalidad de un proceso del crecimiento y que en la actualidad nos encontramos ya dentro de esta fase de la evolución” (1927, p. 2985).

8 Como señala Roger Boesche, este autoritarismo benevolente de Freud enmascara una actitud política paternalista que considera que la mayoría social es inmadura para tomar las decisiones correctas. Ver Boesche (1996, p. 306). En un interesante artículo, el filósofo Luis Alegre defiende las concomitancias entre el gobierno de la razón propuesto por Immanuel Kant y esta 'dictadura' racional de Freud, lo que situaría el proyecto intelectual de este último en la tradición ilustrada, incluso a pesar del hecho de que el descubrimiento de instancias psíquicas inconscientes, especialmente el super-yo, pondrían en un aprieto la confianza moderna en los poderes de la razón. Ver Alegre Zahonero (2010, pp. 155-182). 
No deja de resultar inquietante que Freud tenga la esperanza puesta en una 'dictadura' durante los mismos años en que partidos políticos europeos estaban alcanzando el poder político con unas vanguardias de 'hombres superiores', que habían sido educados en unas ideologías modernas que también reclamaban su racionalidad contra los desórdenes de las democracias. ${ }^{9}$ Que Freud haga estas propuestas, aun reconociendo que se trata de esperanzas poco realizables, testimonia el profundo desprestigio del sistema democrático en la Europa de entreguerras, incluso entre sus pensadores más avanzados.

Ese sometimiento de la parte instintiva de nuestra personalidad, que se presentaba como la amenaza siempre presente de los logros culturales, constituía para Freud el objetivo último de la psicoterapia que había creado. Hacía esa meta se debían dirigir los 'esfuerzos terapéuticos del psicoanálisis': contra los instintos y las pasiones debían lanzar su 'ataque' racional. "Su propósito es robustecer el yo, hacerlo más independiente del super-yo, ampliar su campo de percepción y desarrollar su organización, de manera que pueda apropiarse de nuevas partes del ello. Donde era ello, ha de ser yo" (p. 3146).

De un hombre que buscaba disipar las ilusiones de la humanidad, que se había atrevido a infligir a la orgullosa civilización occidental esa dolorosa herida narcisista que consistía en hacernos saber que "el yo no es dueño y señor en su propia casa” (Freud, 1917, p. 2436), no parece excesivamente realista su intención declarada de conquistar de manera definitiva ese vasto mundo interno donde no rigen los presupuestos de la lógica científica. Además, ese yo tan altivo no sería sino una formación secundaria producida por el contacto con el mundo externo, como el mismo Freud había reconocido solo unas páginas antes de enunciar semejante propósito omnipotente (Freud, 1932, p. 3144).

\footnotetext{
9 En el campo del psicoanálisis, también ha recibido críticas esta desgraciada formulación política de Freud, que parece contradecir su tarea intelectual a favor de la libertad de pensamiento y contra el autoritarismo moral y religioso. Ver, por ejemplo, Fromm (1959, pp. 103-104) y Moscovici (1991).
} 
La relación del yo con el ello podría compararse a la de su jinete con su caballo. El caballo suministra la energía para la locomoción; el jinete tiene el privilegio de fijar la meta y dirigir los movimientos del robusto animal. Pero entre el yo y el ello ocurre frecuentemente el caso, nada ideal, de que el jinete tiene que guiar al caballo allí donde éste quiere ir (p. 3144). ${ }^{10}$

Con la expresión “dictadura de la razón”, Freud estaba, pues, mostrando su deseo de afianzar el control del yo sobre la psique del ciudadano, ya que "el yo representa en la vida anímica la razón y la reflexión, mientras que el ello representa las pasiones indómitas” (p. 3144). Desde este presupuesto, el psicoanalista ilustrado debe embarcarse en la misión militar de reforzar el poder ejecutivo de los ciudadanos sobre un mundo interno que, como la vida misma, está marcado por lo incontrolable. Una década antes de esta deriva dictatorial, Freud ya había avanzado que "el psicoanálisis es un instrumento que ha de facilitar al yo la progresiva conquista del ello" (Freud, 1923, p. 2726). Pero, acto seguido, reconocía que ese yo llamado a conquistar continentes ignotos se comportaba a menudo como "el sumiso servidor que aspira a lograr el amor de su dueño" (p. 2726), que no era otro que ese mismo ello tan refractario a la domesticación.

Más aún, a partir de su labor investigadora, se había visto obligado a reconocer que "un individuo es, ahora, para nosotros, un ello psíquico desconocido e inconsciente, en cuya superficie aparece el yo" (p. 2707). Pues bien, nos resulta, cuanto menos, difícil de aceptar que ese apéndice superficial pueda en algún momento llegar a conquistar y convertirse en el dictador benigno de un espacio amplísimo del que, además, carece de mapas con los que orientarse y diseñar su campaña triunfal. Por el contrario, lo que hallamos es un abismo que separa la realidad y el deseo, y que solo podría ser superado por un puente fabricado por las fantasías de omnipotencia del teórico. Freud, sin

\footnotetext{
10 Ver también Freud (1923, p. 2708), donde usa la misma analogía para explicar las relaciones entre el yo y el ello. Esta metáfora guarda un innegable parecido con la descripción platónica del alma como un auriga que guía dos caballos, uno obediente y otro difícil de manejar. Ver Platón (1988, 246a-b, p. 345).
} 
embargo, parece consciente de la enormidad de la tarea que ha encomendado a su ciencia. Con la intención de situar al yo en el lugar del ello estaríamos hablando de un movimiento análogo al dominio humano sobre la naturaleza, de ganarle terrenos al mar, como habían hecho en Holanda, "es una labor de cultivo como la desecación del Zuyderzee" (Freud, 1932, p. 3146). Toda esta maniobra mental nos deja aún más perplejos si atendemos a la descripción que el mismo autor acababa de plantear al lector sobre las penosas dificultades que el ejecutivo del ciudadano debe afrontar en la vida ordinaria:

[...] conducido por el ello, restringido por el super-yo y rechazado por la realidad, el yo lucha por llevar a cabo su misión... la de establecer una armonía entre las fuerzas y los influjos que actúan en él y sobre él; y comprendemos por qué, a veces, no podemos menos de exclamar: “QQué difícil es la vida!”. Cuando el yo tiene que reconocer su debilidad, se anega en angustia, angustia real ante el mundo exterior, angustia moral ante el super-yo y angustia neurótica ante la fuerza de las pasiones en el ello (p. 3145).

Freud tardará mucho tiempo, casi toda su vida, en reconocer que ese gobierno autoritario de la razón no solo era una tarea imposible, sino también peligrosa (Roiz, 2003, p. 319). Esas ideas no serán su última palabra sobre las posibles soluciones a los desgobiernos de la vida del ciudadano. Creemos, sin embargo, con Hannah Arendt, que lo más estimulante, propio y enriquecedor de los grandes pensadores son precisamente sus contradicciones: "Estas contradicciones tan fundamentales y flagrantes pocas veces se presentan en escritores de segunda línea, en quienes pueden descontarse. En los grandes autores nos llevan hasta el centro mismo de sus obras y son la clave más importante para llegar a la verdadera comprensión de sus problemas y sus nuevos criterios" (Arendt, 1996, p. 31).

\section{Una teoría de los límites}

En las páginas precedentes, hemos abordado una 'solución ideal' a los desgobiernos de la vida de los ciudadanos que, desde la teoría política democrática, no podemos aceptar al estar basada en el recurso 
autoritario a la 'dictadura'. Una dictadura que se nos plantea como inclusiva en algunas de sus versiones, pero que, como procedimiento básicamente ejecutivo, no respeta el buen juicio. Desde la tradición de la retórica mediterránea, representada por autores como el griego Isócrates (436-338 a. E. C.) o el hispanorromano Marco Fabio Quintiliano (c. 35-95 E. C.), se nos ha enseñado a prevenir esta deriva autoritaria que, mediante razonamientos dialécticos, menosprecia la fragilidad y el carácter contingente de los asuntos humanos y que, de hecho, pretende segregar lo considerado como útil, racional o verdadero de lo que, según sus criterios, no lo sería. ${ }^{11}$ Los sueños, las fantasías, los afectos, los sentimientos, así como el sosiego letárgico, serán purgados como estorbos infantiles en la marcha triunfal de la ciencia y la política vigilantes. Esta segregación —a la que también podríamos denominar como mutilación de la experiencia humanaserá llevada al paroxismo por los mecanismos paranoicos de un calvinismo que ha actuado como fermento intelectual de muchas ideas políticas modernas. ${ }^{12}$ Según esta visión de las cosas, compartida por tantos pensadores influyentes, no se puede tener confianza en la vida y, como consecuencia, habrá que adoptar métodos brutales y expeditivos, especialmente si la vida cotidiana es descrita en los términos tan amenazadores que empleaba Juan Calvino (1509-1564): “A cualquier parte que nos volvamos, todo cuanto nos rodea, no solamente es sospechoso, sino que casi abiertamente nos está amenazando y no parece sino que está intentando darnos muerte... Entre tales angustias, ¿no ha de sentirse el hombre miserable?; pues aun en vida, apenas vive, porque anda como si llevase de continuo un cuchillo en la garganta” (Calvino, 2003, I, XVII, 10, p. 145). ${ }^{13}$

Parece claro que, en este ambiente tan hostil y violento, lo más eficaz, el instrumento intelectual necesario para conducirse por la vida y el conocimiento será 'el puño cerrado' de la dialéctica, descartando, a su vez, la pacífica 'mano abierta' de la retórica democrática, inoperativa

\footnotetext{
11 Ver Alonso Rocafort (2010, pp. 154-180). Sobre los elementos democráticos en las enseñanzas de Quintiliano, ver también Roiz (2003, pp. 37-40).

12 Ver Adrián (2012).

13 Citado en Adrián (2012, p. 77).
} 
en estas circunstancias. ${ }^{14}$ Si queremos ser justos, sin embargo, hay que señalar que Freud - a pesar de ese exceso de entusiasmo racionalista que ya hemos comentado - desconfiaba íntimamente de que la mejor manera de alcanzar alguna sabiduría sólida fuese el método dialéctico. Así lo expresa en sus Lecciones introductorias al psicoanálisis, pronunciadas mientras se disputaba una guerra que enfrentaba a media Europa contra la otra mitad: "No creo en la verdad de aquella máxima que pretende que de la discusión nace la luz, máxima que me parece ser un producto de la sofística griega y pecar, como ella, por la atribución de un exagerado valor a la dialéctica" (Freud, 1916, p. 2274). ${ }^{15}$

La dictadura de la razón parece no casar bien con este entendimiento retórico del saber. El hecho revolucionario de tumbar al paciente en el diván, sin mirar directamente al analista, ya supone desactivar un 'modelo belicoso' y vigilante del conocimiento en el que Freud no creía (Roiz, 2003, pp. 316-317). Aunque se haya identificado al psicoanálisis con la 'cura del habla', los discursos serían menos curativos que el silencio, realidad matriz sin la que las palabras, como la música, no tendrían razón de ser. El mismo autor que, quizá desesperado ante la barbarie que se extendía a su alrededor, hacía un llamamiento a una dictadura ilustrada encargada de poner orden en la confusión, reconocía al final de uno de sus trabajos más positivistas que "nuestro dios Logos no es, quizá, muy omnipotente y no puede cumplir sino una pequeña parte de lo que sus predecesores prometieron" (Freud, 1927, p. 2991).

Aparentemente existe una contradicción flagrante entre esta última cita y aquellas otras en las que Freud apostaba por una monarquía científica del intelecto humano que lograría doblegar nuestros impulsos autodestructivos. Pensamos, sin embargo, que no debemos

\footnotetext{
14 "Hay dos géneros de discurso, el uno continuado, que se llama retórico, el segundo cortado, llamado dialéctico, que Zenón a su vez puso en tan estrecha conexión, que comparó a este último con el puño cerrado, al primero con la mano abierta, también el arte disputadora - la dialéctica — será una virtud: en nada habrá dudas sobre la primera, que tiene más belleza y mejor claridad" (Quintiliano, 1997-2001, II.20.6).

15 Debo esta cita a mi compañero de grupo de investigación Jorge Loza Balparda.
} 
ser piadosos con nuestro autor y, por el contrario, podríamos aplicar a sus ideas lo que él mismo afirmaba sobre las nuevas teorías etnográficas que pretendían refutar sus tesis sobre el totemismo primitivo: "Una contradicción no siempre significa una refutación; una nueva teoría no denota necesariamente un progreso" (Freud, 1938, p. 3320). ${ }^{16}$ Por lo tanto, esa ansiada dictadura de la razón, esa idolatría del Logos, tampoco tiene por qué significar un progreso, sino más bien un retroceso, en la elaboración teórico-política de Freud. Más bien nos parece el atajo mágico de un pensador que, a pesar de su rebeldía con lo establecido, seguía atrapado de forma no consciente en el fetichismo moderno de la solución final.

Él mismo era capaz de explicar de forma muy precisa en qué consiste ese delirio filosófico-político que aspira a encontrar la respuesta única y correcta que, a la manera del mito de Edipo, acabaría con los males con los que la misteriosa esfinge azotaba a su ciudad. Freud se dio cuenta tardíamente de la "significativa discrepancia entre nuestro órgano pensante y la organización del mundo que ha de ser aprehendido por medio de nuestro pensamiento" (p. 3305).

Nuestra imperiosa necesidad de hallar nexos causales se conforma con que cada proceso tenga una causa demostrable; pero en la realidad exterior difícilmente sucede tal cosa, pues cada fenómeno parece estar más bien sobredeterminado, presentándose como efecto de múltiples causas convergentes. Intimidado ante la insuperable complejidad del suceder, nuestro conocimiento opta por un nexo determinado, en contra de otro; establece contradicciones inexistentes, sólo debidas a la arbitraria destrucción de relaciones más amplias (p. 3305).

Buscando ese nexo determinado, esa explicación definitiva de las neurosis, se habían extraviado en su propio laberinto algunos discípulos de Freud, como Alfred Adler y Otto Rank. Al menos, esa era la

\footnotetext{
16 Leo Strauss, al analizar esta obra de Freud, resalta esta cita, lo que, tratándose de un lector tan fino como Strauss, podría significar algo más que una simple indicación. Ver Strauss (1997, p. 300).
} 
opinión del maestro. En Inbibición, sintoma y angustia (1926), un Freud apesadumbrado renuncia explícitamente a encontrar la solución final de las neurosis, es decir, de los desgobiernos de la vida del ciudadano. Las represiones del ejecutivo, el yo freudiano, solo sirven para que los elementos reprimidos se hagan aún más libres, soberanos y poderosos "en el dominio de lo inconsciente" (Freud, 1926, p. 2871), escapando de esta forma a un control militarizado que no puede acceder a ese ámbito esencial del mundo interno donde no llegan nuestras funciones cognitivas. Como consecuencia de su intensa labor de investigación en los desgobiernos internos, el teórico reconoce las dificultades que ha encontrado en su empresa. Entre los 'factores' que inciden en la causación de las neurosis, Freud resalta tres, sin que ninguno de ellos sea el definitivo. Esto quiere decir que, aunque aislemos a alguno de ellos, a la manera en que los médicos aíslan los virus o las bacterias, el desgobierno podría reaparecer de una u otra forma. No es posible lograr la inmunidad ante "las dificultades reales de la vida" (p. 2872). Estos tres factores que, según Freud, "han creado las condiciones" para la fragilidad del gobierno de la vida del individuo son "uno biológico, otro filogénico y otro puramente psicológico” (p. 2872). De acuerdo con la explicación que Freud da de cada uno de ellos, además de factores que condicionan los desgobiernos, también pueden considerarse límites insoslayables ante los que la soberbia científica debe replegarse. Pero ¿̇en qué consisten estos límites al gobierno del yo sobre el resto del self? Dejemos hablar a Freud:

El factor biológico es la larga invalidez y dependencia de la criatura humana. La existencia intrauterina del hombre es más breve que la de los animales, siendo así echado al mundo menos acabado que éstos. Con ello queda intensificada la influencia del mundo exterior real e impulsada muy tempranamente la diferenciación del yo y del ello. Además, aparece elevada la significación de los peligros del mundo exterior y enormemente incrementado al valor del objeto que puede servir por sí solo de protección contra tales peligros y sustituir la perdida vida intrauterina. Este factor biológico establece, pues, las primeras situaciones peligrosas y crea la necesidad de ser amado, que ya no abandonará jamás al hombre (p. 2872). 
Freud está apuntando en estas líneas a la necesidad de sobrevivir del infante en un entorno natural, social o político para el que aún no está preparado. Solo es posible escapar a 'los peligros del mundo exterior' mediante las autoridades protectoras, con las que no queda más remedio que establecer una relación de dependencia a cambio de protección. Aquí podríamos hallar también la génesis de la política en sentido amplio. El miedo a la pérdida del amor, con el consiguiente desamparo ante las adversidades, se convierte en el terror más profundo y enloquecedor que podría sufrir el ser humano. De modo que, para evitar a toda costa esa pérdida, el crecimiento biológico del ciudadano va acompañado de la paralela instauración en su mundo interno de una autoridad que recoge, en forma de 'conciencia moral', las normas, tradiciones o preceptos que mantienen unida la comunidad a la que pertenece el nuevo ciudadano. ${ }^{17}$

La desobediencia a estos preceptos - y aunque los deseos rebeldes no se transformen en actos reales - traería consigo el 'sentimiento de culpabilidad', ya que ninguna idea puede ocultarse a la censura de esta autoridad interna y fiscalizadora (Freud, 1930, p. 3056). La necesidad vital de estas autoridades provoca que, además de interiorizarlas, también podamos proyectarlas en creencias que intensifican su poderío idealizado. Las desventuras personales ofrecerían un terreno abonado para que crezcan vigorosas estas ideas mágicas sobre deidades castigadoras que no cesan, ni de día ni de noche, de vigilar nuestros pensamientos ni nuestros actos: "El destino es considerado como un sustituto de la instancia parental; si nos golpea la desgracia, significa que ya no somos amados por esta autoridad máxima” (p. 3055). ${ }^{18}$

El segundo límite al que alude Freud es el denominado 'filogénico' y consiste en "un hecho singularísimo del desarrollo de la libido"

\footnotetext{
17 Ver, por ejemplo, Freud (1932, pp. 3134-3135); y también Freud (1940, pp. 3417-3418).

18 En la reproducción de este mecanismo mental, la virtud cívica, paradójicamente, incrementa el castigo interno del ciudadano: "[...] la conciencia moral... se comporta tanto más severa y desconfiadamente cuanto más virtuoso es el hombre, de modo que, en última instancia, quienes han llegado más lejos en el camino de la santidad son precisamente los que se acusan de la peor pecaminosidad" (Freud, 1930, p. 3055).
} 
que el psicoanálisis habría sido la primera ciencia en resaltar (Freud, 1926, p. 2872). A diferencia de los animales más próximos a la especie humana, esta no desarrolla su sexualidad de forma continua hasta la madurez. Sufre, por el contrario, un parón desde los cinco años hasta la pubertad. La sexualidad, como ya sabemos, era, para Freud, "la etiología más directa de las neurosis" (p. 2873) por ser el origen de fantasías, anhelos o emociones a los que el yo — que ha ido interiorizando durante su crecimiento una autoridad severa y punitiva- responde con represiones, con la institución de una dictadura in foro interno que buscaría repeler los peligros que amenazan la preeminencia del ejecutivo.

La ausencia en el mundo interno de una demarcación rígida y estable entre lo externo y lo interno provoca que el peligro interior sea capaz de provocar una angustia de la misma intensidad que su correlato exterior. Esto nos lleva al tercer factor, el 'psicológico', que Freud atribuye a "una imperfección del aparato anímico, relacionado precisamente con su diferencia en un yo y un ello" (p. 2873). Más que a una imperfección, creemos que Freud alude a una escisión inevitable en el self del ciudadano. Esta ruptura del self sería el producto de su relación temprana con el mundo externo, ante el que se sitúa en una posición frágil y dependiente, compensada con irreales fantasías de omnipotencia con las que pretende alejar los peligros reales. ${ }^{19}$ La dificultad que una y otra vez deberá afrontar el ciudadano para gobernarse a sí mismo residirá en la impotencia de un yo "que no puede protegerse

19 A este respecto, la pensadora estadounidense Judith Butler señala que "el amor del niño es anterior al juicio y la decisión... para poder persistir psíquica y socialmente, debe haber dependencia y formación de vínculos: no existe la posibilidad de no amar cuando el amor está estrechamente ligado a las necesidades básicas de la vida. El niño no sabe a qué se vincula; sin embargo, tanto el bebé como el niño deben vincularse a algo para poder persistir en sí mismos y como sí mismos... el 'yo' sólo puede emerger negando su formación en la dependencia, las condiciones de su propia posibilidad. Sin embargo, se ve amenazado con el desequilibrio por esa negación, por la búsqueda inconsciente de la propia disolución mediante repeticiones neuróticas que reescenifican las situaciones primarias que no sólo se niega a ver, sino que, si desea seguir siendo él mismo, tampoco puede ver. Por supuesto, el hecho de estar fundado sobre algo que se niega a saber significa que está separado de sí mismo y que nunca podrá devenir o permanecer del todo como él mismo" (Butler, 2001, pp. 18-19, 21). 
contra peligros instintivos interiores de un modo tan eficaz como contra una parte de la realidad que no forma parte de él" (p. 2873).

Sin embargo, la idea curativa del límite, antídoto contra la proliferación de fantasías de omnipotencia, ligadas íntimamente a su vez a la reflexión y la creación intelectual, ${ }^{20}$ ya aparece en los primeros tiempos de la labor psicoanalítica de Freud. Así, en La interpretación de los sueños, su obra favorita — una especie de hijo mimado que revisaría y corregiría durante el resto de su vida— ${ }^{21}$ el autor advierte al lector que "la pregunta de si todo sueño puede obtener una interpretación debe ser contestada en sentido negativo" (Freud, 1900, p. 665). De hecho, por la razón que aduce Freud, pareciera que existe una conspiración interna para obstaculizar la labor del investigador de los dominios oníricos: "No debemos olvidar que aquellos poderes psíquicos de los que depende la deformación de los sueños actúan siempre en contra de la labor interpretadora" (p. 665).

Cualquier lector del maestro vienés sabe que Freud hace uso en muchas ocasiones de un lenguaje beligerante. Se consideraba un conquistador de espacios indómitos. Nos lo imaginamos con un machete desbrozando los ramajes agrestes que le impedían seguir su marcha hasta el corazón de la selva de lo inconsciente. Cuando no puede alcanzar su objetivo con una determinada estrategia de investigación, no dudará en emprender su tarea "partiendo de otros distintos puntos de ataque” (p. 657). Su interés por desentrañar el verdadero aspecto del sueño es tal que no dudará en recurrir a la traición e introducir su espada intelectual en las zonas en las que el sueño pueda aparecer desprotegido, ya que, escribe Freud: "Me dan a conocer los puntos débiles del disfraz del sueño, me sirven como a Hagen la señal

\footnotetext{
20 Desde el primer caso en que Freud utiliza la expresión "omnipotencia del pensamiento", establece así mismo un nexo entre neurosis obsesiva, omnipotencia y la pasión por el conocimiento, que se debería a una sobrestimación o erotización de nuestros actos psíquicos. Ver Freud (1909, pp. 1484-1485) y Freud (1913, pp. 1801-1802).

21 Desde 1900, fecha de la primera edición, hasta 1930, aparecieron ocho ediciones, en las que el autor añadía nuevo material con los resultados de sus investigaciones sobre el tema. Podríamos decir, por lo tanto, que se trata de la obra de toda una vida.
} 
bordada en el vestido de Sigfrido" (Freud, 1900b, p. 510). ${ }^{22}$ En esta ocasión, nuestro investigador se identifica con un antihéroe, Hagen, el traidor que acaba asesinando a Sigfrido — la gran figura heroica de la mitología germánica—, apuñalándolo en el único punto de su cuerpo en que podía ser herido. ${ }^{23}$

En estas líneas aparece el Freud aguerrido e iconoclasta, capaz de golpear a traición sobre lo establecido, que no tiene miedo de derribar las instituciones más asentadas para hacernos saber en qué se basan. En esa misma obra, anteriormente ya se había identificado con Aníbal, el guerrero semita que tuvo el coraje de marchar contra Roma, el gran imperio de su tiempo (Freud, 1900, p. 466). Podríamos interpretar ahora que, al elegir a Hagen como su alter ego en su ataque contra las resistencias del sueño, Freud nos está queriendo decir que no teme ofender a la poderosa y racionalista ciencia germana, y enseñar las grietas donde se asienta un edificio que, a pesar de su aparente grandiosidad, también tiene puntos débiles. Uno de ellos sería su constante desprecio a la letargia como elemento esencial del conocimiento sobre la humanidad.

Freud proviene de una tradición, la judía, que ha tratado con veneración a los sueños como una forma privilegiada de comunicación divina. Hijo de Jacob, él ha venido a recoger el testigo de su antepasado bíblico, ese José que alcanzó el poder de Egipto interpretando los sueños del Faraón. Él mismo lo reconoce en una reveladora nota al pie de La interpretación de los sueños: "Detrás de las personas con este nombre [José] puedo ocultar fácilmente mi propio yo, pues también se llamaba así el onirocrítico que la Biblia nos da a conocer" (p. 642, nota 369). ${ }^{24} \mathrm{El}$ papel de los sueños en la sabiduría profética de Jerusalén no puede ser minusvalorado. Con la excepción de Moisés —única persona a la que le está permitida contemplar 'la imagen de Yahveh'-,

\footnotetext{
22 Para esta cita concreta, hemos utilizado excepcionalmente la traducción española de Freud hecha por el argentino José Luis Etcheverry. La referencia a Hagen y Sigfrido no aparece en la versión de Luis López-Ballesteros que hemos citado a lo largo de este trabajo.

23 Ver Cantar de los Nibelungos (2005, cantos XV y XVI).

24 Énfasis en el original.
} 
según el texto bíblico, los demás profetas habrían recibido los mensajes divinos a través de su facultades letárgicas: "Dijo Yahveh: 'Escuchad mis palabras: si hay entre vosotros un profeta, en visión me revelo a él, y hablo con él en sueños" (Números 12: 6). ${ }^{25}$

Por esa razón, además del conquistador intrépido y aguerrido, del Sigmund que, aunque respetuoso con la letargia de su tradición, se enfrenta a los problemas de la psique con la lógica del guerrero y el cuchillo entre las manos, sabemos ya que existe, al menos, otro Freud, ese pequeño Schlomo que, a veces, consigue hacerse oír desde la infancia sepultada por la ambición del científico adulto: quizá su oculto y, a la vez, verdadero self. ${ }^{26}$ Como Salomón, el hijo de David, el rey sabio a quien los compiladores de la Biblia atribuyeron el Qóbelet, Freud también se da cuenta de la vanidad de un conocimiento vigilante que pretende explicar todo cuanto ocurre bajo el sol. ${ }^{27}$ Así, comprende que el poderío de la razón y las armas de la lógica se nos muestran inútiles ante esa parte de nuestra identidad que hay que respetar como inexpugnable. Ante esa noche del alma que no podemos conquistar y que nos regala, sin embargo, un mundo de experiencias valiosas que no están controladas por nuestro poderes ejecutivos. ${ }^{28}$ El reconocimiento de ese límite, paradójicamente, ampliaría nuestra sabiduría sobre la vida. De este modo, pocas páginas después de la referencia a los puntos débiles de Sigfrido, ya en el capítulo final de la obra, Freud escribirá esto:

\footnotetext{
25 Ver al respecto Salberg (2009, pp. 80-102). Para la importancia del sueño y de la facultad imaginativa en Maimónides como precursor sefardita del pensamiento de Freud, ver Roiz (2008, pp. 36-38).

26 Para la diferencia entre 'verdadero' y 'falso' self, ver Winnicott (1960, pp. 140-152).

27 "Cuanto más apliqué mi corazón a estudiar la sabiduría y a contemplar el ajetreo que se da sobre la Tierra — pues ni de día ni de noche concilian los ojos el sueño— fui viendo que el ser humano no puede descubrir todas las obras de Dios, las obras que se realizan bajo el sol. Por más que se afane el hombre en buscar, nada descubre, y el mismo sabio, aunque diga saberlo, no es capaz de descubrirlo" (Eclesiastés 8: 16-17).

28 " [...] la resistencia pierde durante la noche una parte de su poder... y que esta disminución de la resistencia sea lo que hace posible la formación del sueño... la condición principal de la formación de los sueños es el estado de reposo del alma... el estado de reposo hace posible la formación de los sueños, disminuyendo la censura endopsíquica" (Freud, 1900, p. 666). Énfasis en el original.
} 
En los sueños mejor interpretados solemos vernos obligados a dejar en tinieblas determinado punto, pues advertimos que constituye un foco de convergencia de las ideas latentes, un nudo imposible de desatar, pero que por lo demás no ha aportado otros elementos al contenido manifiesto. Esto es entonces lo que podemos considerar como el ombligo del sueño, o sea el punto por el que se halla ligado a lo desconocido. Las ideas latentes descubiertas en el análisis no llegan nunca a un límite y tenemos que dejarlas perderse por todos lados en el tejido reticular de nuestro mundo intelectual. De una parte más densa de este tejido se eleva luego el deseo del sueño (Freud, 1900, p. 666). ${ }^{29}$

Las consecuencias de este fragmento son, en nuestra opinión, un obstáculo insalvable en la marcha triunfal de la ciencia vigilante. Supone, además del reconocimiento benéfico de los poderes de la letargia, la expresión del límite que separa la honesta búsqueda científica de la locura. Aquí creemos percibir la voz del pequeño Schlomo que se ríe de las pretensiones dictatoriales del adulto Sigmund. El verdadero self de Freud nos advierte que ese emperador, que deseaba someter el mundo interno a la monarquía de una razón hipostasiada, está desnudo. La interpretación racional no es capaz, ni en las mejores condiciones, de desentrañar el misterio de ese mundo interno que existe, a pesar de que no entendamos su lenguaje y aunque ni siquiera seamos capaces de escucharlo. Ese mundo que hay que dejar 'en tinieblas' nos constituye, forma la parte esencial del self del ciudadano, aunque se trate de 'un nudo imposible de desatar'.

Freud tuvo la valentía intelectual de reconocer su existencia para, al mismo tiempo, admitir que "se halla ligado a lo desconocido". Toda la soberbia musculatura racional del psiquiatra debe aceptar su impotencia para frenar una maraña de ideas que 'tenemos que', es decir, nos vemos obligados a "dejarlas perderse por todos lados en el tejido reticular de nuestro mundo intelectual". Nuestro autor llama a ese objeto tan desconocido como trascendental "el ombligo

29 Énfasis añadido. 
del sueño" (der Nabel des Traums). ${ }^{30}$ No creemos que ese nombre sea una mera casualidad. En una obra tan cuidada como La interpretación de los sueños, y en un punto tan delicado como al que nos referimos, el nombre elegido para designar a este nudo inextricable tenía que tener una razón de peso, aunque Freud no quisiera, o no pudiese, desvelarla a sus lectores.

Ese ombligo onírico evoca esa cicatriz corporal que marca a todo ciudadano, una cicatriz que testimonia nuestra más ancestral limitación, pues se trata de la prueba indeleble de que todos hemos dependido radicalmente de otra persona. El ombligo del sueño conecta así con ese 'factor biológico' que condiciona que nuestros desgobiernos no admitan ninguna solución final. Las 'ideas latentes' de las que habla Freud se mueven en la infinitud porque provienen de un self desvalido que compensa su vulnerabilidad mediante fantasías de omnipotencia que, aunque irrealizables, no puede dejar de reproducir como señal de supervivencia. La 'vía regia' al conocimiento del mundo interno que comenzaba con el apuñalamiento victorioso de Sigfrido y prosigue con el desciframiento del enigma edípico acaba ante las puertas impenetrables del ombligo del sueño. Esa cicatriz del psiquismo humano señala imperturbable una cuarta herida narcisista, ${ }^{31}$ que afectaría de lleno al propio psicoanálisis, que ya solo podrá continuar su objetivo omnipotente de restaurar el trono del yo del ciudadano ignorando que esa idolatría tiene los pies de barro.

\footnotetext{
30 No es la primera vez que aparece esta idea en La interpretación de los sueños. Mucho antes, en el capítulo II, mientras analiza su famoso sueño de la inyección de Irma, escribirá en una nota al pie: "Todo sueño presenta por lo menos un fragmento inescrutable, como un cordón umbilical por el que se hallase unido a lo incognoscible” (Freud, 1900, p. 415, nota 218). Sobre este punto, ver la interesante reflexión de Jonte-Pace (2001, pp. 29-33).

31 Las otras tres heridas narcisistas que la ciencia moderna habría infligido al ser humano serían, según Freud, los descubrimientos de Copérnico (ofensa cosmológica), Darwin (ofensa biológica) y los del propio Freud (ofensa psicológica). Así, nos hemos visto obligados a aceptar que la Tierra no es el centro del universo, que el hombre forma parte de una especie animal y que el yo no es el soberano del alma humana. Ver Freud (1917, pp. 2432-2436).
} 


\section{Lo interminable}

El artículo "Análisis terminable e interminable", escrito en 1937, apenas dos años antes de la muerte del autor, ha sido ampliamente comentado por sus indicaciones sobre la aplicación práctica o técnica de sus descubrimientos psicológicos. Para nosotros, sin embargo, supone mucho más que la última palabra de Freud sobre la terapia psicoanalítica. Representa más bien un estudio donde resurge esa teoría política democrática e innovadora, poscopernicana podríamos llamarla, ${ }^{32}$ donde se cuestionan de manera profunda y sabia las posibilidades de que el ejecutivo pueda lograr el gobierno del self del ciudadano. De hecho, ese control del yo sobre nuestra identidad equivaldría a un desgobierno lesivo para el mundo interno del individuo. El reconocimiento de los límites de ese poder ejecutivo y consciente, encarnado en la memoria y la voluntad, ${ }^{33}$ significa una salida teórica del laberinto de la omnipotencia del pensamiento. Una posibilidad de respirar una atmósfera democrática.

En un determinado momento del texto aparece la expresión "transferencia negativa” como algo que, según le reprochó cierto paciente - en una nota al pie del editor, se nos aclara que tal paciente fue Sándor Ferenczi- ${ }^{34}$ al haber sido dejado sin analizar, condujo al fracaso del análisis. No solo arruinó los resultados de la terapia, sino que aquel hombre se convirtió en 'antagonista' del analista (Freud, 1937, p. 3343). Freud trata este fracaso en tercera persona, esto es, como si

\footnotetext{
32 Ver Roiz (1998, pp. 9-18). Sobre el paralelismo entre la revolución copernicana, la teoría de la evolución de Darwin y el descubrimiento freudiano del inconsciente, ver Khun (1976, p. 4).

33 Sobre este asunto, ver Roiz (2013, pp. 87, 102, 163-164, 173, 282). Para una distinción, a nuestro juicio, necesaria entre una memoria 'roja', voluntaria o predadora, y una memoria 'verde', independiente del pensamiento consciente, ver Roiz (1992, pp. 65-68).

34 Según cuenta Ferenczi en su diario clínico sobre su experiencia con Freud: "Mi análisis propio no pudo llegar hasta una profundidad suficiente porque mi analista (él mismo, confesadamente, una naturaleza narcisista), con su enérgica voluntad de salud y su antipatía por las debilidades y anormalidades, no pudo seguirme hasta esas profundidades e introdujo lo 'pedagógico' demasiado pronto” (Ferenczi, 1997, p. 109).
} 
concerniera a otras personas ajenas a su vida cercana, y no a él mismo y a quien había sido su amigo íntimo y confidente durante décadas.

Pero el lector se da cuenta de que está hablando de algo que le molesta personalmente, o quizá deberíamos decir que le hiere. No en vano Freud estaba muy orgulloso de haber descubierto las posibilidades curativas de la transferencia, una situación terapéutica que iba más allá del logos, ya que implicaba una apertura del self en que el analizado transmitía "un trozo importante de su vida" como no hubiera sido posible hacerlo solo mediante el lenguaje. "En cierto modo actúa ante nosotros, en lugar de contarlo" (Freud, 1940, p. 3398). La dramaturgia no consciente implicada en la relación transferencial ayudaría a reparar desgobiernos del individuo. Esto en el caso de que esa transferencia fuese positiva. Si, por el contrario, la transferencia es del signo opuesto, es decir, negativa, el 'pacto' terapéutico podría estar amenazado de muerte. En los últimos años de su vida, esta realidad dolorosa, esta herida narcisista, fue adquiriendo un mayor protagonismo, al darse cuenta de que su aparición era inevitable. En su último trabajo inconcluso, comenta con pesimismo esta posibilidad:

La transferencia, al reproducir los vínculos con los padres, también asume su ambivalencia. No se podrá evitar que la actitud positiva frente al analista se convierta algún día en negativa, hostil... Una vez que la transferencia negativa adquiere supremacía, [los éxitos terapéuticos] son barridos como el polvo por el viento. Advertimos con horror que todos los esfuerzos realizados han sido vanos. Hasta lo que podíamos considerar como un progreso intelectual definitivo del paciente — su comprensión del psicoanálisis, su confianza en la eficacia de éste- ha desaparecido en un instante (pp. 3398-3399).

Nuestro autor debía tener este fenómeno muy presente cuando previene en el "Análisis terminable e interminable" contra las ilusiones optimistas de dar por terminada una terapia de una vez por todas. Quizá también debió recordar esa intuición de Ferenczi de considerar el optimismo como un remanente en el ciudadano adulto de las fantasías infantiles de omnipotencia (Ferenczi, 1913, p. 165). 
Las expectaciones del optimista presuponen claramente un número de cosas que no son precisamente evidentes por sí mismas. Suponen, en primer lugar, que realmente existe una posibilidad de solucionar un conflicto instintivo (o, más correctamente, un conflicto entre el yo y un instinto) definitivamente y para siempre; en segundo lugar, que mientras estamos tratando a alguien por un conflicto instintivo, podemos, de la manera que sea, inmunizarlo contra la posibilidad de cualquier otro conflicto de ese tipo, y en tercer lugar, que podemos, con propósitos de profilaxis, resolver un conflicto patógeno de esta clase que no se manifiesta en el momento por ninguna indicación y que es aconsejable hacerlo así (Freud, 1937, p. 3344). ${ }^{35}$

Una terapia, por muy exitosa que sea, piensa Freud, no puede dar una solución final ni tampoco otorgar la inmunidad ni servir de método profiláctico respecto a los conflictos, riesgos o desgobiernos que nos depare un futuro que nadie nunca conoce. Aparece aquí, de nuevo, ese Freud rétor, maestro de ciudadanos, que confía en la oratioperpetua como medio de reconocimiento de la contingencia y de protección contra las soluciones mágicas, y a la larga estériles, del conocimiento dialéctico. Como un estribillo, esta idea de la irrealidad de que el psicoanálisis pueda alcanzar una solución final se repite musicalmente en diversos lugares de este texto. Así, se nos dice, por ejemplo, que, "si el paciente que ha sido curado nunca produce otro trastorno que necesite psicoanálisis, no sabemos hasta qué punto su inmunidad no es debida a un hado benéfico que le ha ahorrado tormentos demasiado graves" (Freud, 1937, p. 3342). Respecto a la posibilidad de una 'domesticación del instinto' (p. 3345) producto de un yo reforzado, se nos aclara que las partes domeñadas del mundo interno pueden volver a rebelarse y desgobernarnos de nuevo "por causas accidentales en cualquier otro período de nuestra vida" (p. 3346). El creador se permite dudar incluso de que la técnica por él creada marque una diferencia sustancial entre quienes han hecho uso de ella y entre quienes no: "Tenemos la impresión de que no deberíamos sorpren-

\footnotetext{
35 Énfasis añadido.
} 
dernos si al final encontramos que la diferencia entre la conducta de una persona que no ha sido psicoanalizada y la de otra después de haberlo sido no es tan completa como intentamos realizarla ni como lo esperamos y como afirmamos que ha de ser" (p. 3347).

No nos atrevemos a afirmar que estas líneas sean una cura de humildad, aunque ciertamente lo parezcan, pero sí las señalamos como un ejemplo de honestidad intelectual que es justo reconocer. Freud pensaba al final de su carrera que era poco menos que insensato considerar que un análisis pudiera darse alguna vez por terminado completamente. Él se estaba refiriendo concretamente a la terapia psicoanalítica, pero, teniendo en cuenta la amplitud de miras de Freud, creemos justificado suponer que esta opinión podría aplicarse a cualquier otro ámbito no solo del conocimiento, sino también de la vida humana. Por supuesto que la terapia podía y debía concluir, ${ }^{36}$ lo que ya considera demasiado 'ambicioso', y a tenor de lo que acabamos de exponer, incluso descabellado, es que fuese posible establecer mediante la aplicación técnica de la teoría "un nivel de normalidad psíquica absoluta", es decir, que "hubiéramos logrado resolver cada una de las represiones del paciente y llenar todas las lagunas de su memoria" (p. 3347).

Otros psicoanalistas, como Otto Rank, pretendieron haber conseguido dar con la clave de las neurosis, en su caso el trauma del nacimiento, y creyeron posible que, analizando ese hecho, el desgobierno humano se esfumaría. Freud entiende las buenas intenciones de ese intento, pero lo descarta como un producto "diseñado para adaptar el tempo de la terapia analítica a la prisa de la vida americana” (p. 3339). Demasiadas

\footnotetext{
36 "Antes que nada hemos de decidir qué se quiere decir con la frase ambigua 'el final de un análisis'. Desde un punto de vista práctico, es fácil contestar. Un análisis ha terminado cuando el psicoanalista y el paciente dejan de reunirse para las sesiones de análisis. Esto sucede cuando se han cumplido más o menos por completo dos condiciones: primera, que el paciente no sufra ya de sus síntomas y haya superado su angustia y sus inhibiciones; segun$\mathrm{da}$, que el analista juzgue que se ha hecho consciente tanto material reprimido, que se han explicado tantas cosas que eran ininteligibles y que se han conquistado tantas resistencias internas, que no hay que temer una repetición de los procesos patológicos en cuestión. Si dificultades externas impiden la consecución de esta meta, es mejor hablar de un análisis incompleto que de un análisis inacabado" (Freud, 1937, p. 3341).
} 
circunstancias en la vida escapan a nuestra voluntad ejecutiva, y el remedio a nuestros desgobiernos cotidianos es precisamente una de ellas, quizás el asunto más fugitivo o esquivo de cuales nos toque afrontar. Ese ansiado estado de perfecto equilibrio es un ensueño cuya persecución provocará, por su irrealidad, más frustración y sufrimiento que bienestar. "En el mundo real", aclara Freud, "las transiciones y los estadios intermedios son mucho más comunes que los estados opuestos, claramente diferenciados" (p. 3347). Otra idea errónea —a pesar de haber sido tan ensalzada por la dialéctica moderna- que Freud pretende desacreditar es la de superación, es decir, la creencia de que, mediante la ciencia, se pueden dejar atrás los conflictos, las supersticiones o los defectos que enturbian una pretendida higiene social o cultural. En nuestro mundo interno, nunca nada se supera, sino que lo pasado convive con lo presente y convivirá con lo futuro. La marcha triunfal del espíritu humano hacia un porvenir glorioso no es más que otra ilusión omnipotente:

De todas las creencias erróneas y supersticiosas de la Humanidad, que se supone que han sido superadas, no existe ninguna cuyos residuos no se hallen hoy entre nosotros, en los estratos más bajos de los pueblos civilizados o en las capas superiores de la sociedad culta. Lo que una vez ha llegado a estar vivo se aferra tenazmente a conservar la existencia. A veces nos sentimos inclinados a dudar de si los dragones de los tiempos prehistóricos están realmente extintos (p. 3348).

La excesiva fe en nuestras capacidades ejecutivas sería la responsable de este desaguisado intelectual que se repite una y otra vez durante las sucesivas épocas históricas. Walter Benjamin, durante los mismos años, sentía la misma desazón ante ese pasado pisoteado por un presente insensible que ya auguraba un futuro escalofriante: " $¿ N o$ nos roza, pues, a nosotros mismos un soplo de aire que envolvió a los antecesores? ¿No existe en las voces a que prestamos oídos un eco de las ahora enmudecidas? ¿No tienen las mujeres a las que cortejamos unas hermanas que ellas no han conocido ya? Si es así, hay entonces una cita secreta entre las generaciones pasadas y la nuestra" (Benjamin, 2008, p. 306). 
En la ciencia, además, se ha instalado un mito de la normalidad muy perjudicial porque plantea un modelo ideal que no se da en la experiencia cotidiana. En la labor concreta de Freud, esto acarrea ulteriores problemas porque la ficción teórica de la normalidad es un constructo que puede convertirse en la cárcel mental del pensador. De esta forma, el investigador debe admitir que "el yo anormal, que no sirve para nuestros propósitos, no es, por desgracia, una ficción”, sino la realidad más común, la materia prima de su trabajo. Un yo que, además, "bajo la influencia de la educación” va a establecer una guerra consigo mismo, intentando, con gran sacrificio, "dominar el peligro interno antes de que se convierta en peligro externo" (Freud, 1937, p. 3352). Para ello cuenta con los llamados 'mecanismos de defensa, entre los que sobresale la 'represión' (p. 3353).

Esta guerra interna deja destrozos graves en el mundo interno del ciudadano. En ocasiones, irreparables. Esas defensas del ejecutivo actúan en un entorno psíquico marcado por un único esquema, el de la omnipotencia. ${ }^{37}$ Tarde o temprano, estos mecanismos represivos, agresivos y dictatoriales, de partes del mundo interno contra otras partes del mismo llevarían a un callejón sin salida. No es útil, sin embargo, la analogía con una represión de la ciudad externa, ya que "no podemos huir de nosotros mismos; la huida no es un remedio frente a un peligro interno" (p. 3353). La estrategia represiva del yo contra los rebeldes que emergen del océano de la no consciencia puede desembocar en un desgobierno más lesivo del que se pretendía evitar. ${ }^{38}$ De conducirnos de esta manera, viviríamos "condenados a falsificar

\footnotetext{
37 "El aparato psíquico no tolera el displacer, ha de eliminarlo a todo costa, y si la percepción de la realidad lleva consigo el displacer, aquella percepción — esto es la verdad— debe ser sacrificada" (Freud, 1937, p. 3353).

38 Nos resulta muy sugerente la analogía que Benjamin evoca entre el mar y lo incognoscible, que también es el estrato más profundo e incontrolable de lo que nos hace humanos, y que encuentra en la noche su morada. "Este mar del sueño en el fondo mismo de la naturaleza humana tiene a la noche su marea viva: todo adormecerse sólo indica que ese extenso mar baña una playa de la que se retira en la vigilia... El mar es un símbolo de la naturaleza humana. Como sueño — en el sentido más profundo, es decir, figurado— lleva ésta al navío de la vida dentro de su corriente, la cual es guiada desde la lejanía por el viento y los astros; como adormecimiento, tomado en sentido literal, asciende de noche, tal como lo hace la marea sobre la que es la playa de la vida, donde deja los sueños" (Benjamin, 2011, pp. 70-71).
} 
nuestra percepción interna", a tratar nuestro mundo interno a partir de una "imagen imperfecta y desfigurada" (pp. 3353-3354). Por ese motivo, Freud sostiene que, si bien es cierto que "los mecanismos de defensa sirven al propósito de alejar los peligros... es cierto que, a su vez, pueden convertirse en peligros. A veces resulta que el yo ha pagado un precio demasiado alto por los servicios que le prestan" (p. 3354). Traduciendo el vocabulario psicoanalítico a una terminología política, podríamos decir que un yo demasiado armado, un ejecutivo demasiado inflado, en lugar de asegurar un buen gobierno eficaz o estable, provoca una deformación paranoica con las características de una tiranía in foro interno:

El yo del adulto, con su fuerza incrementada, continúa defendiéndose contra peligros que ya no existen en la realidad; se siente impulsado a buscar en la realidad aquellas situaciones que pueden servir como un sustituto aproximado del peligro primitivo para poder justificar, en relación con ellas, el que mantengan sus modos habituales de reacción. Así podemos comprender fácilmente cómo los mecanismos defensivos, produciendo una alienación más amplia del mundo exterior y una debilitación permanente del yo, facilitan y pavimentan el camino para la irrupción de la neurosis (p. 3354).

Como consecuencia, se complica la tarea del analista de restablecer un buen gobierno en el self. La desconfianza sentida tanto ante los ingredientes letárgicos, que surgen sin respetar la lógica vigilante, como ante una autoridad exterior que pretende aliviar el desgobierno llevan a la cura analítica a una situación difícil: "El yo considera la curación un nuevo peligro" (p. 3354). Sentimientos inconscientes de culpa que, de manera masoquista, ofrecen al yo como víctima propiciatoria para un castigo ejemplar producen una activación violenta de "una fuerza que se defiende con todos los medios posibles contra la curación y que se halla completamente resuelta a aferrarse a la enfermedad y al sufrimiento" (p. 3357). ${ }^{39}$ Pero ¿a qué se deberían estas resistencias inconscientes del yo si se supone que en ese lugar de la topografía

39 Sobre la relación entre la severidad del super-yo inconsciente y esta necesidad de castigo 
psíquica anida la conciencia? Ante estas dificultades, cada vez más consistentes y numerosas, el Freud más sabio y maduro ya no sostiene con firmeza esa cartografía del mundo interno con la que, de forma un tanto soberbia, lo había dividido en tres naciones psíquicas, el yo, el ello y el super-yo, con fronteras constantemente disputadas. Así, reconociendo que el yo, esa instancia a la que el psicoanálisis estaba destinado a proteger, también se halla dominado habitualmente por una distorsión no consciente de las realidades interna y externa, ${ }^{40}$ Freud asume que "pierde mucho de su valor para nuestra investigación la distinción topográfica entre lo que es yo y lo que es ello" (p. 3356). El mismo autor que solo varios años antes aspiraba a instaurar una 'dictadura de la razón' y que pretendía, con metáforas militares, que el yo invadiese el ello, acepta ahora indirectamente, pero con serenidad, que esos proyectos eran ilusiones autoritarias sin mucho fundamento.

\section{Conclusión: profesiones insaciables}

La profunda transformación política de su país, y de su ciudad, Viena, donde había transcurrido prácticamente toda su vida, quizás influyó en Freud más de lo que su yo estaría dispuesto a aceptar. Los años treinta austríacos estuvieron marcados por intentos dictatoriales nacionalistas e insurrecciones socialistas y obreras, así como por el hostigamiento incesante del fascismo que venía del sur italiano y del nazismo amenazador que crecía imparable en el norte alemán.

Existe, sin embargo, una prueba escrita de cómo estos avatares políticos y sociales llegaron a influir en el fundador del psicoanálisis. Nos referimos a los dos prefacios contradictorios que anteceden a la tercera y última parte de Moisés y la religión monoteísta. Uno está escrito

por medio de la enfermedad, ver también, por ejemplo, Freud (1932, pp. 3162-3163) y Freud (1940, p. 3401).

40 En su último libro publicado en vida, Moisés y la religión monoteísta, Freud escribe: "Es cierto que todo lo reprimido es inconsciente, pero ya no es del todo cierto que cuanto pertenezca al yo sea también consciente. Advertimos que la consciencia es una cualidad fugaz, sólo transitoriamente adherida a un proceso psíquico... diremos, con más justeza, que el yo es esencialmente preconsciente (virtualmente consciente), pero que algunas partes del yo son inconscientes" (1938, p. 3299). 
en Viena y fechado antes de marzo de 1938. El segundo lo escribió en junio de ese mismo año "en la hermosa, libre y generosa Inglaterra" (Freud, 1938, p. 3273). Londres será el lugar de acogida de la familia Freud tras huir de la persecución racista exacerbada tras el Anschluss del 12 de marzo de 1938, por el que Austria pasaba a ser una provincia del Tercer Reich.

Freud pensaba que el último baluarte de la independencia austríaca era la Iglesia católica, por eso no creía conveniente publicar su estudio sobre Moisés y sus subversivas conclusiones sobre la religión en general. De todas formas, redactó, de forma clandestina, ese breve primer prefacio donde reflejaba sus sensaciones sobre las turbulencias políticas en que se encontraba inmerso: "Vivimos en una época harto extraña. Comprobamos, asombrados, que el progreso ha concluido un pacto con la barbarie" (p. 3272). La Rusia soviética, la Italia fascista y la Alemania nazi son los tres ejemplos que, para Freud, certifican ese siniestro acuerdo. Esos tres países se habrían convertido en unos regímenes aborrecibles que contradicen su fe ilustrada en el progreso de la humanidad. En los tres casos, unas vanguardias iluminadas se habían hecho con un poder político absoluto que habían utilizado para eliminar la libertad de pensamiento. En lugar de armonía social, la represión de los disidentes solo habría causado un incalculable destrozo cultural. No nos debería extrañar, por lo tanto, que el último Freud renunciara a sus veleidades autoritarias y que dejara de propugnar cualquier tipo de dictadura, por muy benigna que aspirase a ser. Al fin y al cabo, las denostadas democracias liberales habían sido quienes mejor habían sabido proteger y respetar sus controvertidas teorías (p. 3272).

Como Edipo, Freud se vio obligado a emprender el duro camino del exilio, vilipendiado y humillado por sus descubrimientos, y a dejar atrás su ciudad, ahora desgarrada por un cruento conflicto civil. Y al igual que el héroe trágico, también tendrá a su lado a su Antígona, su hija Anna, quien le servirá de báculo cuando desfallezcan sus fuerzas y que continuará, como psicoanalista, el legado de su padre. ${ }^{41}$

\footnotetext{
41 El mismo Freud solía llamar 'su Antígona' a Anna. Ella fue, además, la única de entre sus hijos que se dedicó al psicoanálisis (Gay, 2010, p. 493).
} 
El desgobierno y la inestabilidad política ya eran monedas de curso común en Austria cuando Freud escribía su "Análisis terminable e interminable". Por ello, conviene saber interpretar sus apuntes sobre la autoridad del analista. Se trataba de un problema espinoso. Si bien su labor era esencial, también era muy arriesgada: el analista, al arrogarse el derecho a establecer un gobierno interno, puede provocar daños muy hondos en el sujeto que se analiza. Freud es consciente de que ese peligro existe y no rebaja su riesgo potencial: "Parece que cierto número de psicoanalistas aprenden a utilizar mecanismos defensivos que les permiten desviar de sí mismos las implicaciones y exigencias del análisis (probablemente dirigiéndolas hacia otras personas), de modo que ellos siguen siendo como son y pueden sustraerse a la influencia crítica y correctiva del psicoanálisis... cuando un hombre está investido de poder le resulta difícil no abusar de él" (Freud, 1937, p. 3362).

Una tarea tan delicada necesita algún instrumento que prevenga este tipo de abusos. La respuesta de Freud a este problema es convertir el psicoanálisis en 'una tarea interminable', de forma que "todo analista debería periódicamente —a intervalos de unos cinco años- someterse a un nuevo análisis sin sentirse avergonzado de dar este paso" (p. 3362). Lo que nos resulta interesante, además, para nuestro propósito, es el hecho de que, para responder a las críticas que se le hacían a su ciencia sobre este asunto, Freud integre al psicoanálisis dentro de un conjunto de tres profesiones que califica como 'imposibles'. "Parece casi como si la de psicoanalista fuera la tercera de esas profesiones 'imposibles' en las cuales se está de antemano seguro de que los resultados serán insatisfactorios. Las otras dos, conocidas desde hace mucho más tiempo, son la de la educación y la del gobierno" (p. 3361).

¿Por qué dice Freud que profesiones tan cotidianas como la educación o el gobierno son imposibles? Conocemos a muchas personas que, con mayor o menor talento, y con mayor o menor fortuna, se dedican a ellas. Nuestro autor ya señala el motivo de su pesimismo respecto al desempeño de estas profesiones, pues en lo concerniente a ellas "se está de antemano seguro de que los resultados serán insatisfactorios”. 
Pero ¿'insatisfactorios' respecto a qué estándar o medida? Ese es justamente el problema, en nuestra opinión. Adquirir e impartir conocimientos y gobernar una ciudad o un país son tareas que siempre pueden ampliarse, que no consiguen satisfacción. Son profesiones insaciables. De hecho, el deseo subjetivo de perfeccionamiento y control no conoce límite porque toca de lleno, y a diario, la fantasía de omnipotencia del ser humano, a la que ningún saber le parecerá suficiente ni considerará perfecta ninguna forma de gobierno. El psicoanálisis que, en su esencia, busca conjugar la pedagogía y el gobierno del mundo interno, también ha de afrontar la fuerza arrolladora de la omnipotencia que, para Freud, constituye uno de los fundamentos de la psique humana.

Las enseñanzas de Freud como teórico político, sus advertencias sobre los desgobiernos autoritarios que rigen nuestras vidas y el intenso sufrimiento que implican, y al que ningún ciudadano, no importa su clase o rango, es inmune, nos incitan a seguir investigando sobre la necesidad de un gobierno democrático del ciudadano. Sabemos, también gracias a él, que esa tarea es interminable. Pero, desde una teoría política democrática, también es un trabajo inexcusable. Pues, como nos recordaba Sheldon S. Wolin, otro maestro de nuestra disciplina, "la democratización de la política se queda en algo meramente formal sin la democratización del self" (Wolin, 2008, p. 289). ${ }^{42}$

\section{Referencias}

Alonso Rocafort, V. (2010). Retórica, democracia y crisis. Un estudio de teoría política. Madrid: Centro de Estudios Políticos y Constitucionales.

Adrián, L. (2012). Dialéctica y calvinismo en la teoría política contemporánea (Tesis doctoral, Universidad Complutense de Madrid).

Alegre Zahonero, L. (2010). La libertad civil como condición de posibilidad de la autonomía moral. Sobre la aportación de Freud al planteamiento práctico de Kant. Trans/Form/Açao, 33(1), 155-182.

42 Traducción propia. 
Arendt, H. (1996). La tradición y la época moderna. En H. Arendt, Entre elpasado y el futuro. Ocho ejercicios de reflexión política. Trad. de Ana Poljak. Barcelona: Península.

Benjamin, W. (2008). Sobre el concepto de historia. En W. Benjamin, Obras, libro I/vol. 2. Trad. de Alfredo Brotons. Madrid: Abada.

Benjamin, W. (2011). Sueños. Trad. de Juan Barja y Joaquín Chamorro Mielke. Madrid: Abada.

Boesche, R. (1996). Theories of tyranny. University Park, Pennsylvania: The Pennsylvania State University Press.

Butler, J. (2001). Mecanismos psíquicos del poder. Teorías sobre la sujeción. Madrid: Cátedra.

Calvino, J. (2003). Institución de la religión cristiana. Trad. de Cipriano de Valera (1597), reeditada por Luis Usoz y Río (1858), actualizada por la Fundación Editorial de Literatura Reformada (1967), volumen I. Madrid: Visor.

Cantar de los Nibelungos. (2005). Edición de Emilio Lorenzo Criado. Madrid: Cátedra.

Ferenczi, S. (1913). Estadios en el desarrollo del sentido de realidad. En S. Ferenczi (1959), Sexo y psicoanálisis. Buenos Aires: Hormé/Paidós. Ferenczi, S. (1997). Sin simpatía no hay curación. El diario clínico de 1932. Buenos Aires: Amorrortu.

Freud, S. (1900a). La interpretación de los sueños. En S. Freud (2001), Obras completas, tomo 2. Trad. de Luis López-Ballesteros y de Torres. Madrid: Biblioteca Nueva.

Freud, S. (1900b). La interpretación de los sueños (segunda parte). En S. Freud (1991), Obras completas, vol. 5. Trad. de José L. Etcheverry. Buenos Aires: Amorrortu.

Freud, S. (1909). Análisis de un caso de neurosis obsesiva ("Caso el Hombre de las Ratas”). En S. Freud (2001), Obras completas, tomo 4, trad. de Luis López-Ballesteros y de Torres. Madrid: Biblioteca Nueva.

Freud, S. (1913). Tótem y tabú. En S. Freud (2001), Obras completas, tomo 5. Trad. de Luis López-Ballesteros y de Torres. Madrid: Biblioteca Nueva.

Freud, S. (1916). Lecciones introductorias al psicoanálisis. En S. Freud (2001), Obras completas, tomo 6. Trad. de Luis López-Ballesteros y de Torres. Madrid: Biblioteca Nueva. 
Freud, S. (1917). Una dificultad del psicoanálisis. En S. Freud (2001), Obras completas, tomo 7. Trad. de Luis López-Ballesteros y de Torres. Madrid: Biblioteca Nueva.

Freud, S. (1918). El tabú de la virginidad. En S. Freud (2001), Obras completas, tomo 7. Trad. de Luis López-Ballesteros y de Torres. Madrid: Biblioteca Nueva.

Freud, S. (1923). El yo y el ello. En S. Freud (2001), Obras completas, tomo 7. Trad. de Luis López-Ballesteros y de Torres. Madrid: Biblioteca Nueva. Freud, S. (1925). Autobiografía. En S. Freud (2001), Obras completas, tomo 7. Trad. de Luis López-Ballesteros y de Torres. Madrid: Biblioteca Nueva. Freud, S. (1926). Inhibición, síntoma y angustia. En S. Freud (2001), Obras completas, tomo 8. Trad. de Luis López-Ballesteros y de Torres. Madrid: Biblioteca Nueva.

Freud, S. (1927). El porvenir de una ilusión. En S. Freud (2001), Obras completas, tomo 8. Trad. de Luis López-Ballesteros y de Torres. Madrid: Biblioteca Nueva.

Freud, S. (1930). El malestar en la cultura. En S. Freud (2001), Obras completas, tomo 8. Trad. de Luis López-Ballesteros y de Torres. Madrid: Biblioteca Nueva.

Freud, S. (1932). Nuevas lecciones introductorias al psicoanálisis. En S. Freud (2001), Obras completas, tomo 8. Trad. de Luis López-Ballesteros y de Torres. Madrid: Biblioteca Nueva.

Freud, S. (1933). El porqué de la guerra. En S. Freud (2001), Obras completas, tomo 8. Trad. de Luis López-Ballesteros y de Torres. Madrid: Biblioteca Nueva.

Freud, S. (1937). Análisis terminable e interminable. En S. Freud (2001), Obras completas, tomo 9. Trad. de Luis López-Ballesteros y de Torres. Madrid: Biblioteca Nueva.

Freud, S. (1938). Moisés y la religión monoteísta. En S. Freud (2001), Obras completas, tomo 9. Trad. de Luis López-Ballesteros y de Torres. Madrid: Biblioteca Nueva.

Freud, S. (1940). Compendio de psicoanálisis. En S. Freud (2001), Obras completas, tomo 9. Trad. de Luis López-Ballesteros y de Torres. Madrid: Biblioteca Nueva.

Fromm, E. (1959). Sigmund Freud's mission: an analysis of his personality and influence. New York: Harper.

Gay, P. (2010). Freud. Vida y legado de un precursor. Barcelona: Paidós. 


\section{6 / Juan Dorado Romero}

Jonte-Pace, D. (2001). Speaking the unspeakable. Religion, misogyny, and the uncanny mother in Freud's cultural texts. Berkeley: University of California Press.

Khun, T. (1976). The Copernican Revolution: planetary astronomy in the development of western thought. Cambridge and London: Harvard University Press. Moscovici, M. (1991). Il est arrivé quelque chose. Paris: Payot.

Platón. (1988). Fedro. En Platón, Diálogos III. Trad. de Emilio Lledó. Madrid: Gredos.

Platón. (2002). República. Trad. de José Manuel Pabón y Manuel FernándezGaliano. Madrid: Alianza.

Quintiliano, M. F. (1997-2001). Sobre la formación del orador (institutionis oratoriae), edición bilingüe, trad. de Alfonso Ortega Carmona, doce libros repartidos en cinco tomos. Salamanca: Universidad Pontificia de Salamanca.

Rieff, P. (1966). Freud. La mente de un moralista. Buenos Aires: Paidós.

Roiz, J. (1992). El experimento moderno. Madrid: Trotta.

Roiz, J. (1998). La democracia vigilante. Caracas: Cipost.

Roiz, J. (2003). La recuperación del buen juicio. Madrid: Editorial Foro Interno.

Roiz, J. (2008). Sociedad vigilante y mundo judio en la concepción del Estado. Madrid: Editorial Complutense.

Roiz, J. (2013). El mundo interno y la política. Madrid: Plaza y Valdés.

Salberg, J. (2009). Dreams and authoritative knowledge: bridging Judaism and psychoanalysis. En L. Aron \& L. Henik (Eds.), Answering a question with a question. Contemporary psychoanalysis and Jewish Thought. Brighton (MA): Academic Studies Press.

Spinoza, B. (2013). Ética. Trad. de Vidal Peña. Madrid: Alianza.

Strauss, L. (1997). Freud on Moses and monotheism. En L. Strauss, Jewish philosophy and the crisis of modernity. Essays and lectures in modern Jewish Thought. Ed. de Kenneth Hart Green. Albany: State University of New York Press.

Voegelin, E. (1990). On Hegel: A study in sorcery. En E. Voegelin, Published essays. 1966-1985. The collected works of Eric Voegelin. Baton Rouge and London: Louisiana State University Press.

Winnicott, D. W. (1960). Ego distortions in terms of true and false self. En D. W. Winnicott (2007), The maturational processes and the facilitating environment. London: Karnac Books. 
Wolin, S. S. (1991). On the theory and practice of power. En J. Arac (Ed.), After Foucault. Humanistic knowledge, postmodern challenges. New Brunswick: Rutgers University Press.

Wolin, S. S. (2008). Democracy Inc. managed democracy and the specter of inverted totalitarianism. Princeton: Princeton University Press. 
